\section{Whirling Disease in Trout}

WHIRLING disease, long recognized as a scrious problem in the intensive rearing of salmonid fish in Europe, has now been found in Scotland. In October 1968, the myxosporidian protozoan parasite Myxosoma cerebralis, the aetiological agent of the disease, was identified in rainbow trout (Salmo gairdnerii) from two trout farms. In recent years the disease has appeared in North America, USSR and Japan, but the causative parasite has not previously been identified in Great Britain.

The following symptoms (which have been described previously ${ }^{1-4}$ ) were observed in the thirty-nine 6-8 month old rainbow trout examined: blackened tails, spinal curvature and exhaustive tail chasing movements; at the same time mortalities occurred. Microscopical preparations of wet mounts of head cartilage (Fig. 1) revealed the presence of the spores of $M$. cerebralis from which polar filaments were extruded following the application of 5 per cent $\mathrm{NaOH}$ to the wet mount material. Further, numerous spores were found in sections of head cartilage (Fig. 2). Infection occurs during the first year of life ${ }^{2}$, usually in the first few weeks of active fecding and before the formation of bone; at this stage the cartilage is most susceptible and the effects most severe. Survivors become carriers of the disease as spores of the myxosporidian remain in the tissues for up to three years.

It is possible that the disease already existed in wild populations before the present diagnosis, but it is also

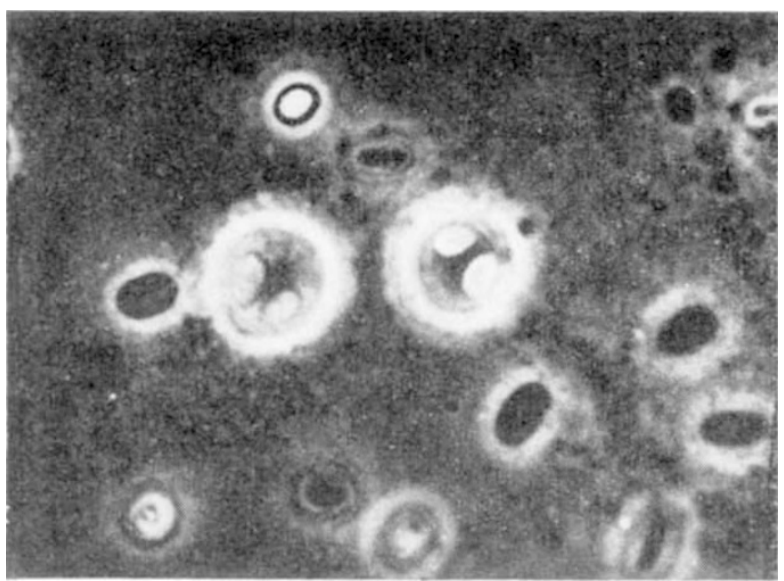

Fig. 1. Photomicrograph showing two spores of Myxosoma cerebralis from posterior part of the cranium. Wet mount by phase contrast mierostopy $(\times 1,200)$.

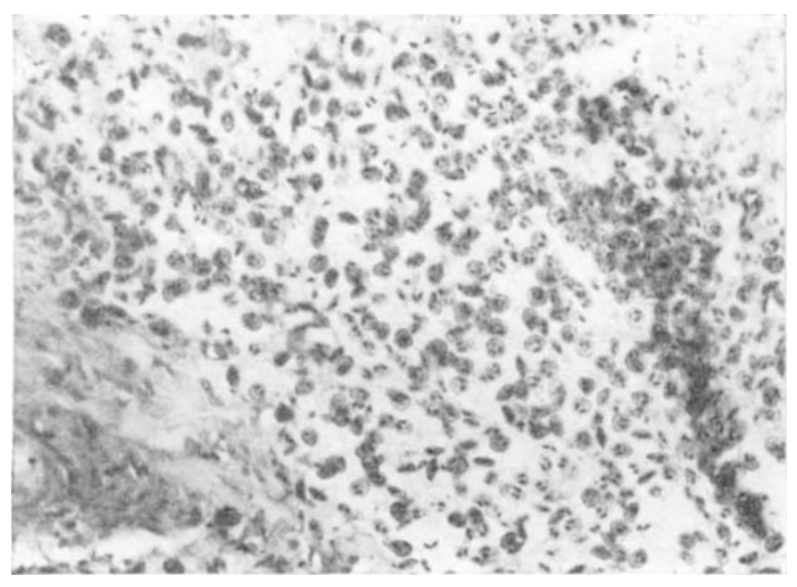

Fig. 2. Photomicrograph of Myxosoma cerebralis in cartilage of young Rainbow trout. Giemsa's stain $(\times 250)$. possible that spores of $M$. cerebralis may have been introduced to Scotland via egg packing materials. In the United States the authorities consider that samples of frozen table fish, which were either accidentally fed or their viscera discarded into streams, were the direct cause of the initial outbreak in North America. In the four months subsequent to this first record of an outbreak of whirling disease in Scotland, the parasite was found in trout from two other fish farms and, on a symptomatic basis, it is not impossible that a further two fish farms are also affected. This illustrates how rapidly a previously unrecognized discase, which may or may not have already existed in the wild in Britain, appeared over a period of months in several widely spread fish farms apparently from a single source.

I thank Dr Iain Anderson (Unilever Research Laboratory) for the preparation of the sections and the photomierographs of the $M$. cerebralis spores.

Department of Agriculture and

K. G. R. ELSON

Fisheries for Scotland,

Marine Laboratory,

PO Box 101,

Victoria Road,

Torry, Aberdeen.

Received May 9; reviscd July 14, 1969.

1 Ylehn, M., Archiv. für Protisterkunde, Bd., 5, 145 (1904)

2 Schäperclaus, W., Fischkrankheiten (Akademic-Verlag, Berlin, 1954).

${ }^{a}$ Uspenskaya, A. V., Lectures Acad. Sci., USSR, 105, 1132 (1955).

${ }^{4}$ Hoffman, G. L., Dunbar, C. F., and Bradtord, A., Spec. Sci. Rep. Fish. US Fish Wildlife Service, 427 (1962).

\section{Circadian Rhythmicity in Photo- periodically Induced Gonadotrophin Release and Gonadal Growth in the Quail}

IN 1936 Bünning1,2 suggested that living organisms measured the length of the daily photoperiod by using an endogenous daily (circadian) rhythm which he envisaged as consisting of two half-cycles (the photophil followed by the scotophil) each of approximately $12 \mathrm{~h}$ duration ${ }^{2}$. Photoperiodic induction of a physiological procoss requiring long days occurred only when the duration of the natural photoperiod extended into the scotophil part of the endogenous cycle. A more explicit version of the Bünning hypothesis has been presented by Pittendrigh ${ }^{3,4}$, stressing the dual function of light in acting both as an entraining agent (or Zeitgeber) for the circadian oscillation and as the photoperiodic inducer. He has also emphasized that the "scotophil" may not last for a full $12 \mathrm{~h}$ and suggests the more restrictive term "photo-inducible phase" to refer to that portion of the daily oscillation which, if illuminated, leads to photoperiodic induction. There is now good evidence available to support Bünning's hypothesis in plants ${ }^{5,6}$, and in at least four species of finches where the photoperiodic induction of testicular growth also relies on a circadian rhythm ${ }^{7-16}$. The present studies in a Galliform species, the Japancse quail (Coturnix coturnix japonica $)^{17-20}$, were undertaken not only to check whether a circadian oscillator was involved in the photo. periodic response mechanism of both sexes but also to measure the duration of the photo-inducible phase. Experiments on the latter seemed possible, for Coturnix shows an extremely high rate of gonadal development ${ }^{18}$

All birds were rearcd under a non-stimulatory photoperiod of $6 \mathrm{~h}$ light per day $(6 \mathrm{~L} / 18 \mathrm{D})$, the experimental schedules being started at either 21 or 28 days of age. They were usually killed when the combined testicular or ovarian weight was $₹ 1,000$ or $₹ 100 \mathrm{mg}$ respectively; this ensured that the rate $(k)$ of gonadal development could be calculated, for growth to these points is log. 